Volume 3, No. 2 Januari 2020

\title{
PENINGKATAN HASIL BELAJAR IPA TENTANG KETERGANTUNGAN MANUSIA DAN HEWAN PADA TUMBUHAN MELALUI METODE KARYA WISATA PADA SISWA KELAS V SLB-A TPA JEMBER
}

\author{
HARIJANTO, S.Pd \\ SLB-A TPA JEMBER
}

\begin{abstract}
ABSTRAK
Tujuan dilaksanakan penelitian ini adalah untuk meningkatkan hasil belajar IPA tentang ketergantungan manusia dan hewan pada tumbuhan melalui metode karya wisata pada siswa kelas V SLB-A TPA Jember. Penelitian ini merupakan penelitian tindakan (action research), yang meliputi planning (perencanaan), action (tindakan), observation (pengamatan), dan reflection (refleksi). Penelitian ini bertempat di SLB-A TPA Jember, pada bulan september. Subyek penelitian adalah siswa-siswi kelas V SLB-A TPA Jember pada pokok bahasan tentang ketergantungan manusia dan hewan pada tumbuhan. Hasil kegiatan pembelajaran yang telah dilakukan selama dua siklus, dan berdasarkan seluruh pembahasan serta analisis yang telah dilakukan dapat disimpulkan bahwa, hasil belajar IPA pada materi pokok ketergantungan manusia dan hewan pada tumbuhan kelas V SLB-A TPA Jember dapat meningkat melalui penerapan metode karya wisata. hal ini dapat dilihat bahwa hasil akhir siklus pembelajaran ke II ini semakin meningkat dibanding siklus I, dari rata-rata $60 \%$ menjadi $81,67 \%$. dengan demikian, dapat dikatakan hasil belajar ipa pada siklus II dinilai telah tuntas.
\end{abstract}

Kata kunci: hasil belajar, IPA, ketergantungan manusia dan hewan pada tumbuhan, metode karya wisata

\section{PENDAHULUAN}

Dewasa ini pendidikan di sekolah-sekolah, khususnya di SLB-A telah menunjukkan perkembangan yang sangat pesat. Perkembangan itu terjadi karena terdorong adanya pembaharuan tersebut, sehingga di dalam pembelajaranpun guru selalu ingin menemukan metode dan peralatan baru yang dapat memberikan semangat belajar bagi siswa-siswa.

Bahkan secara keseluruhan dapat dikatakan bahawa pembaharuan dalam system pendidikan yang mencakup seluruh komponen yang ada. Pembangunan di bidang pendidikan barulah ada artinya apabila dalam pendidiakn dapat dimanfaatkan sesuai dengan kebutuhan masyarakat dan bangsa Indonesia yang sedang membangun.

Kegiatan pembelajaran adalah suatu proses interaksi atau hubungan timbal balik antara guru dan siswa dalam satuan pembelajaran. Guru sebagai salah satu komponen dalam proses belajar menganjar merupakan pemegang peran yang sangat penting. Guru bukan hanya sekedar penyampai materi saja, tetapi lebih dari itu guru dapat dikatakan sebagai sentral pembelajaran.

Sebagai fasilitator sekaligus pelaku dalam proses pembelajaran, gurulah yang mengarahkan bagaimana proses pembelajaran itu dilaksanakan. Karena itu guru harus dapat membuat suatu pembelajaran menjadi lebeh efektif juga menarik sehingga pelajaran yang disampaikan akan 
membuat siswa merasa senang dan merasa perlu untuk mempelajari pelajaran tersebut.

Guru mengemban tugas yang berat untuk tercapainya tujuan pendidikan nasional yaitu meningkatkan kualitas manusia Indonesia, manusia seutuhnya yang beriman dan bertakwa terhadap Tuhan Yang Maha Esa, berbudi pekerti luhur, berkepribadian, berdisiplin, bekerja keras, tangguh, bertanggung jawab, mandiri, cerdas dan terampil serta sehat jasmani dan rohani, juga harus mampu menumbuhkan dan memperdalam rasa cinta terhadap tanah air, mempertebal semangat kebangsaan dan rasa kesetiakawanan sosial. Sejalan dengan itu pendidikan nasional akan mampu mewujudkan manusia-manusia pembangunan dan membangun dirinya sendiri serta bertanggung jawab atas pembangunan bangsa (Depdikbud, 1999).

Berhasilnya tujuan

pembelajaran ditentukan oleh banyak faktor diantaranya adalah faktor guru dalam melaksanakan proses pembelajaran, karena guru secara langsung dapat mempengaruhi, membina dan meningkatkan kecerdasan serta keterampilan siswa. Untuk mengatasi permasalahan di atas dan guna mencapai tujuan pendidikan secara maksimal, peran guru sangat penting dan diharapkan guru memiliki cara/metode mengajar yang baik dan mampu memilih metode pembelajaran yang tepat dan sesuai dengan konsepkonsep mata pelajaran yang akan disampaikan.

Untuk itu diperlukan suatu upaya dalam rangka meningkatkan http://doi.org/10.31537/speed.v3i2.280 mutu pendidikan dan pembelajaran salah satunya adalah dengan memilih strategi atau cara dalam menyampaikan materi pelajaran agar diperoleh peningkatan prestasi belajar pada mata pelajaran IPA. Misalnya dengan membimbing siswa untuk bersama-sama terlibat aktif dalam proses pembelajaran dan mampu membantu siswa berkembang sesuai dengan taraf intelektualnya akan lebih menguatkan pemahaman siswa terhadap konsep-konsep yang diajarkan. Pemahaman ini memerlukan minat dan motivasi. Tanpa adanya minat menandakan bahwa siswa tidak mempunyai motivasi untuk belajar. Untuk itu, guru harus memberikan stimulus dalam bentuk motivasi sehingga dengan bantuan itu siswa dapat keluar dari kesulitan.

Berdasarkan pengalaman penulis di SLB-A TPA Jember, kegagalan dalam belajar khususnya mata pelajaran IPA kelas $\mathrm{V}$ rata-rata dihadapi oleh siswa yang kurang memiliki dorongan belajar. Untuk itu dibutuhkan suatu kegiatan yang dilakukan oleh guru dengan upaya membangkitkan motivasi belajar siswa, misalnya dengan membimbing siswa untuk terlibat langsung dalam kegiatan yang melibatkan siswa serta guru yang berperan sebagai pembimbing untuk menemukan konsep IPA.

Motivasi tidak hanya menjadikan siswa terlibat dalam kegiatan akademik, motivasi juga penting dalam menentukan seberapa jauh siswa akan belajar dari suatu kegiatan pembelajaran atau seberapa 
jauh menyerap informasi yang disajikan kepada mereka. Siswa yang termotivasi untuk belajar sesuatu akan menggunakan proses kognitif yang lebih tinggi dalam mempelajari materi itu, sehingga siswa itu akan meyerap dan mengendapan materi itu dengan lebih baik. Tugas penting guru adalah merencanakan bagaimana guru mendukung motivasi siswa (Nur, 2001, hlm 3). Untuk itu sebagai seorang guru disamping menguasai materi, juga diharapkan dapat menetapkan dan melaksanakan penyajian materi yang sesuai kemampuan dan kesiapan anak, sehingga menghasilkan penguasaan materi yang optimal bagi siswa.

Berdasarkan uraian tersebut di atas penulis mencoba menerapkan salah satu metode pembelajaran, yaitu metode Karyawisata. Metode Karyawisata adalah suatu cara penyajian bahan pelajaran dengan membawa siswa langsung kepada obyek yang akan dipelajari di luar kelas. Dalam hubungannya dengan kegiatan pembelajaran, pengertian karyawisata berarti siswa-siswa mempelajari suatu obyek di tempat mana obyek tersebut berada. Karyawisata dapat dilakukan dalam waktu singkat beberapa jam saja ataupun cukup lama sampai beberapa hari. Dan diharapkan pada pendidik agar bisa mengajarkan siswa membuat laporan dan didiskusikan bersama dengan peserta didik yang lain serta didampingi oleh pendidik.

Kadang-kadang dalam proses pembelajaran siswa perlu diajak ke luar sekolah, untuk meninjau tempat tertentu atau obyek yang lain. http://doi.org/10.31537/speed.v3i2.280
Roestiyah mengemukakan

Karyawisata bukan sekedar rekreasi, tetapi untuk belajar atau memperdalam pelajarannya dengan melihat kenyataannya. Karena itu dikatakan metode karya wisata, ialah cara mengajar yang dilaksanakan dengan mengajak siswa ke suatu tempat atau obyek tertentu di luar sekolah untuk mempelajari atau menyelidiki sesuatu seperti meninjau pabrik pertanian, periakanan, museum, dan sebagainya (Surahmad, 2000, hlm. 31).

Dari latar belakang di atas, maka penulis dalam Penelitian Tindakan Kelas (PTK) ini mengambil judul, "Peningkatan Hasil Belajar IPA Tentang Ketergantungan Manusia dan Hewan Pada Tumbuhan Melalui Metode Karya Wisata Pada Siswa Kelas V SLB-A TPA Jember ."

Penulis mengharapkan dengan hasil penelitian ini dapat memberikan informasi tentang metode pembelajaran yang sesuai dengan materi IPA Kelas V, meningkatkan hasil belajar pada pelajaran IPA Kelas $\mathrm{V}$ dan dapat mengembangkan metode pembelajaran yang sesuai dengan mata pelajaran IPA Kelas V.

\section{METODE}

Menurut

pengertiannya penelitian tindakan adalah penelitian tentang hal-hal yang terjadi dimasyarakat atau sekolompok sasaran, dan hasilnya langsung dapat dikenakan pada masyarakat yang bersangkutan (Arikunto, 2002, hlm. 82). Ciri atau karakteristik utama dalam penelitian tindakan adalah adanya partisipasi dan kolaborasi antara peneliti dengan anggota 
kelompok sasaran. Penelitian tidakan adalah satu strategi pemecahan masalah yang memanfaatkan tindakan nyata dalam bentuk proses pengembangan invovatif yang dicoba sambil jalan dalam mendeteksi dan memecahkan masalah. Dalam prosesnya pihak-pihak yang terlibat dalam kegiatan tersebut dapat saling mendukung satu sama lain.

Sedangkan tujuan penelitian tindakan harus memenuhi beberapa prinsip sebagai berikut:

1. Permasalahan atau topik yang dipilih harus memenuhi kriteria, yaitu benar-benar nyata dan penting, menarik perhatian dan mampu ditangani serta dalam jangkauan kewenangan peneliti untuk melakukan perubahan.

2. Kegiatan penelitian, baik intervensi maupun pengamatan yang dilakukan tidak boleh sampai mengganggu atau menghambat kegiatan utama.

3. Jenis intervensi yang dicobakan harus efektif dan efisien, artinya terpilih dengan tepat sasaran dan tidak memboroskan waktu, dana dan tenaga.

4. Metodologi yang digunakan harus jelas, rinci, dan terbuka, setiap langkah dari tindakan dirumuskan dengan tegas sehingga orang yang berminat terhadap penelitian tersebut dapat mengecek setiap hipotesis dan pembuktiannya.

5. Kegiatan penelitian diharapkan dapat merupakan proses kegiatan yang berkelanjutan http://doi.org/10.31537/speed.v3i2.280 (on-going), mengingat bahwa pengembangan dan perbaikan terhadap kualitas tindakan memang tidak dapat berhenti tetapi menjadi tantangan sepanjang waktu (Arikunto, 2002, hlm. 82-83).

Sesuai dengan jenis penelitian yang dipilih, yaitu penelitian tindakan, maka penelitian ini menggunakan metode penelitian tindakan dari Kemmis dan Taggart (1998, hlm. 14), yaitu berbentuk spiral dari siklus yang satu ke siklus yang berikutnya. Setiap siklus meliputi planning (perencanaan), action (tindakan), observation (pengamatan), dan reflection (refleksi). Langkah pada siklus berikutnya adalah perncanaan yang sudah direvisi, tindakan, pengamatan, dan refleksi. Sebelum masuk pada siklus 1 dilakukan tindakan pendahuluan yang berupa identifikasi permasalahan. Siklus spiral dari tahap-tahap penelitian tindakan kelas dapat dilihat pada gambar berikut:
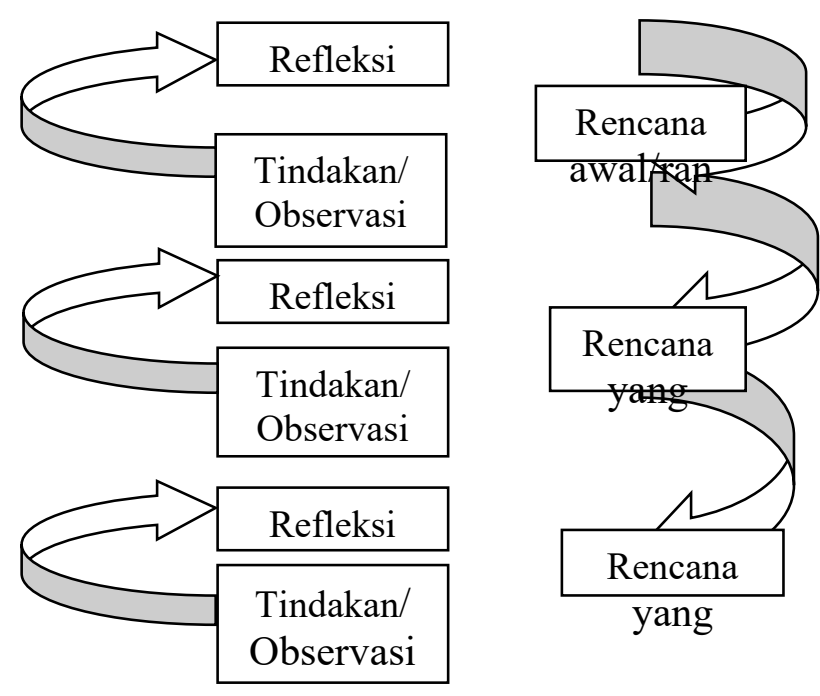
Gambar 1. Alur Penelitian Tindakan Kelas

Penjelasan alur di atas adalah:

1. Rancangan/perencana awal, sebelum mengadakan penelitian peneliti menyusun rumusan masalah, tujuan dan membuat rencana tindakan, termasuk di dalamnya instrumen penelitian dan perangkat pembelajaran.

2. Pelaksanaan dan pengamatan, meliputi tindakan yang dilakukan oleh peneliti sebagai upaya membangun pemahaman konsep siswa serta mengamati hasil atau dampak dari diterapkannya metode Karya Wisata.

3. Refleksi, peneliti mengkaji, melihat dan mempertimbangkan hasil atau dampak dari tindakan yang dilakukan berdasarkan lembar pengamatan yang diisi oleh pengamat.

4. Rencana yang direvisi, berdasarkan hasil refleksi dari pengamat membuat rangcangan yang direvisi untuk dilaksanakan pada siklus berikutnya.

Penelitian ini dilaksanakan selama tiga siklus/putaran.Observasi dibagi dalam tiga putaran, yaitu putaran 1, 2, dan 3, dimana masing putaran dikenai perlakuan yang sama (alur kegiatan yang sama) dan membahas satu sub pokok bahasan yang diakhiri dengan tes formatif di akhir masing putaran. Dibuat dalam tiga putaran dimaksudkan untuk

http://doi.org/10.31537/speed.v3i2.280 memperbaiki sistem pembelajaran yang telah dilaksanakan.

Tempat penelitian adalah tempat yang digunakan dalam melakukan penelitian untuk memperoleh data yang diinginkan. Penelitian ini bertempat di SLB-A TPA Jember.

Waktu penelitian adalah waktu berlangsungnya penelitian atau saat penelitian ini dilangsungkan. Penelitian ini dilaksanakan pada bulan September.

Subyek penelitian adalah siswa-siswi Kelas V SLB-A TPA Jember, pada 1 siswa yang bernama Ridatul Fadila, pada pokok bahasan tentang Ketergantungan Manusia dan Hewan Pada Tumbuhan.

Untuk mengetahui keefektifan suatu metode dalam kegiatan pembelajaran perlu diadakan analisa data. Pada penelitian ini menggunakan metode analisis deskriptif kualitatif, yaitu suatu metode penelitian yang bersifat menggambarkan kenyataan atau fakta sesuai dengan data yang diperoleh dengan tujuan untuk mengetahui prestasi belajar yang dicapai siswa juga untuk memperoleh respon siswa terhadap kegiatan pembelajaran serta aktivitas siswa selama proses pembelajaran.

Untuk menganalisis tingkat keberhasilan atau persentase keberhasilan siswa setelah proses pembelajaran setiap putarannya dilakukan dengan cara memberikan evaluasi berupa soal tes tertulis pada setiap akhir putaran.

Analisis ini dihitung dengan menggunakan statistik sederhana yaitu: 
1. Untuk menilai ulangan atau tes formatif

Peneliti melakukan penjumlahan nilai yang diperoleh siswa, yang selanjutnya dibagi dengan jumlah siswa yang ada di kelas tersebut sehingga diperoleh rata-rata tes formatif dapat dirumuskan:

$\bar{X}=\frac{\sum X}{\sum N}$

Dengan :

$\bar{X}=$ Nilai rata-rata

$\Sigma \mathrm{X}=$ Jumlah semua nilai siswa

$\Sigma \mathrm{N}=$ Jumlah siswa

2. Untuk ketuntasan belajar

Ada dua kategori ketuntasan belajar yaitu secara perorangan dan secara klasikal. Karena hanya ada 1 siswa maka siswa dikatakan telah tuntas belajar bila telah mencapai skor $80 \%$ atau nilai 80 atau telah mencapai KKM. Untuk menghitung persentase ketuntasan belajar digunakan rumus sebagai berikut:

$$
P=\frac{\sum \text { Skor_Yang_Diperoleh }}{\sum \text { Skor_Maksimal }} x 100 \%
$$

\section{HASIL DAN PEMBAHASAN} Siklus I

Tindakan siklus I dilaksanakan pada tanggal 02-06 September 2013. Waktu yang dibutuhkan setiap pertemuan yaitu dua jam pelajaran atau 2 x 35 menit. Pelaksanaan pembelajaran pada Siklus I ini sesuai dengan RPP I, yang disusun dengan langkah-langkah pembelajaran yang meliputi: kegiatan awal, kegiatan inti, dan kegiatan akhir.

Tindakan siklus I ini dilaksanakan dengan menerapkan proses pembelajaran menggunakan Metode Karya Wisata pada pokok bahasan tentang Ketergantungan Manusia dan Hewan Pada Tumbuhan, dengan langkah-langkah sebagaimana tertuang dalam Rencana Pelaksanaan Pembelajaran (RPP) ke I.

Observasi

dilaksanakan bersama proses pembelajaran melalui lembar pengamatan yang meliputi, aktifitas siswa, pengembangan materi, motivasi siswa dalam kegaitan pembelajaran, proses pembelajaran, serta hasil pembelajaran melalui tes akhir.

Data hasil belajar pada kegiatan siklus 1 yang diambil kepada siswa di akhir kegiatan Siklus 1. Secara terperinci hasil belajar IPA pada materi pokok Ketergantungan Manusia dan Hewan Pada Tumbuhan dapat dijelaskan pada tabel berikut.

Tabel 1. Hasil Belajar IPA Kelas V Siklus I

\begin{tabular}{|c|c|c|c|}
\hline \multirow{2}{*}{$\begin{array}{c}\text { Pertemua } \\
\mathrm{n}\end{array}$} & \multicolumn{3}{|c|}{ Aspek } \\
\cline { 2 - 4 } & $\begin{array}{c}\text { Kognit } \\
\text { if }\end{array}$ & $\begin{array}{c}\text { Afekt } \\
\text { if }\end{array}$ & $\begin{array}{c}\text { Psikomotor } \\
\text { ik }\end{array}$ \\
\hline Ke 1 & 70 & 60 & 50 \\
\hline Ke 2 & 60 & 70 & 50 \\
\hline Rata-rata & 65 & 65 & 50 \\
\hline
\end{tabular}

Nilai Akhir $\begin{aligned}: \frac{65+60+50}{3} \\ =\mathbf{6 0 \%}\end{aligned}$ 


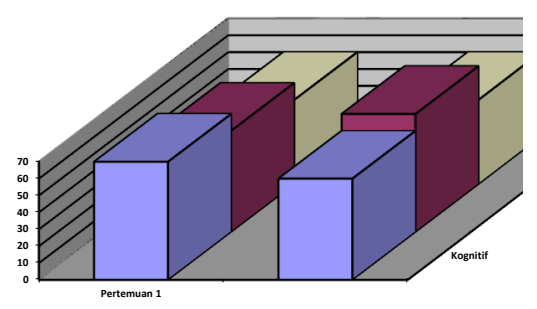

\section{Gambar 2. Grafik Hasil Belajar IPA Kelas V Siklus I}

Hasil refleksi berdasarkan tabel di atas, pada siklus I masih belum menunjukkan hasil yang memuaskan bahwa kemampuan siswa dalam memahami materi pembelajaran tentang Ketergantungan Manusia dan Hewan Pada Tumbuhan dengan Metode Karya Wisata, hasil belajar siswa serta pemahaman terhadap materi pembelajaran masih kurang maksimal. Hasil tersebut menunjukkan bahwa pada siklus I ini siswa belum tuntas belajar, karena nilai siswa hanya mencapai $60 \%$ lebih kecil dari prosentase ketuntasan yang dikehendaki yaitu sebesar $80 \%$.

Siklus II

Tindakan siklus II dilaksanakan pada tanggal 09-13 September 2013. Waktu yang dibutuhkan setiap pertemuan yaitu dua jam pelajaran atau $2 \times 35$ menit. Pelaksanaan pembelajaran pada Siklus II ini sesuai dengan RPP II, yang disusun dengan langkah-langkah pembelajaran yang meliputi: kegiatan awal, kegiatan inti, dan kegiatan akhir.

Tindakan siklus II ini dilaksanakan dengan menerapkan proses pembelajaran menggunakan Metode Karya Wisata pada pokok bahasan tentang Ketergantungan Manusia dan Hewan Pada Tumbuhan, http://doi.org/10.31537/speed.v3i2.280 dengan langkah-langkah sebagaimana tertuang dalam RPP II. Perbedaan dengan siklus I tertelak pada variasi dalam penerapan Metode Karya Wisata. Pada siklus I, dilengkapi dengan media-media lain terkait dengan materi Ketergantungan Manusia dan Hewan Pada Tumbuhan.

Observasi dilaksanakan bersama proses pembelajaran melalui lembar pengamatan yang meliputi, aktifitas siswa, pengembangan materi, motivasi siswa dalam kegaitan pembelajaran, proses pembelajaran, serta hasil pembelajaran melalui tes akhir. Pada siklus II ini peneliti berusaha untuk memperbaiki kekurangan dan kelemahan pada siklus I.

Data hasil belajar pada kegiatan siklus II yang diambil kepada siswa di akhir kegiatan Siklus II. Secara terperinci hasil belajar IPA pada materi pokok Ketergantungan Manusia dan Hewan Pada Tumbuhan dapat dijelaskan pada tabel berikut:

Tabel 2. Hasil Belajar IPA Kelas V Siklus II

\begin{tabular}{|c|c|c|c|}
\hline \multirow{2}{*}{$\begin{array}{c}\text { Pertemua } \\
\mathrm{n}\end{array}$} & \multicolumn{3}{|c|}{ Aspek } \\
\cline { 2 - 4 } & $\begin{array}{c}\text { Kognit } \\
\text { if }\end{array}$ & $\begin{array}{c}\text { Afekt } \\
\text { if }\end{array}$ & $\begin{array}{c}\text { Psikomotor } \\
\text { ik }\end{array}$ \\
\hline Ke 1 & 80 & 90 & 70 \\
\hline Ke 2 & 90 & 80 & 80 \\
\hline Rata-rata & 85 & 85 & 75 \\
\hline
\end{tabular}

Nilai Akhir $\quad: \underline{85+85+75}$

: 81,67\% 


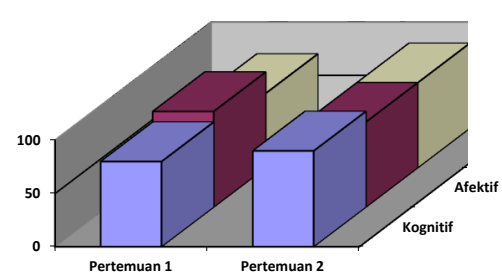

Gambar 2. Grafik Hasil Belajar IPA Kelas V Siklus II

Hasil refleksi berdasarkan tabel di atas, pada siklus II telah menunjukkan hasil yang memuaskan bahwa kemampuan siswa dalam memahami materi pembelajaran tentang Ketergantungan Manusia dan Hewan Pada Tumbuhan dapat meningkat Metode Karya Wisata. Hasil tersebut menunjukkan bahwa pada siklus II ini siswa telah dikatakan tuntas, karena nilai siswa hanya mencapai $81,67 \%$ atau lebih besar dari prosentase ketuntasan yang dikehendaki yaitu sebesar $80 \%$. Adapun peningkatan hasil belajar dari siklus I ke siklus II dapat dilihat pada bagan berikut ini.
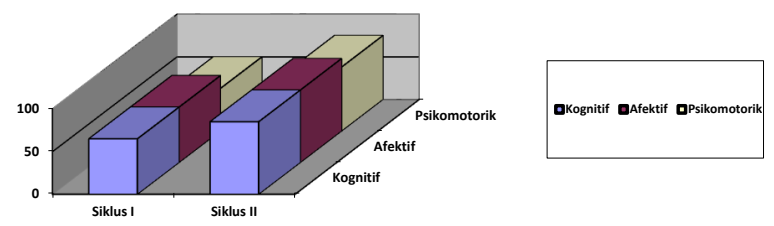

Gambar 3. Peningkatan Hasil Belajar Siklus I dan Siklus II

Hasil penelitian pembelajaran pada siklus I, untuk peningkatan hasil belajar IPA tentang Ketergantungan Manusia dan Hewan Pada Tumbuhan di Kelas V SLB-A TPA Jember masih belum sepenuhnya dipahami siswa.

http://doi.org/10.31537/speed.v3i2.280
Beberapa hal yang menyebabkan ini adalah:

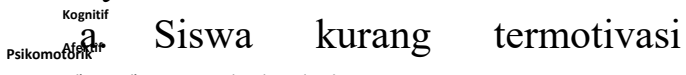

Psilomotorik untuk belajar IPA

b. Metode yang diterapkan guru masih belum bisa membuat siswa aktif dalam pembelajaran di kelas.

c. Hasil akhir siklus pembelajaran ke I ini semakin meningkat dibanding sebelum siklus, dari rata-rata $40 \%$ menjadi $60 \%$. Namun, masih kategori belum tuntas.

Pada siklus II ini pengamatan yang diperoleh adalah:

a. Antusias siswa untuk mengikuti pembelajaran semakin meningkat, karena pembelajaran dengan metode penemuan lebih jelas dan terarah.

b. Interaksi antar guru dan siswa juga sering terjadi karena guru memperhatikan dan menghargai ide atau pendapat siswa.

c. Hasil akhir siklus pembelajaran ke II ini semakin meningkat dibanding siklus I, dari rata-rata $60 \%$ menjadi $81,67 \%$. Dengan demikian, dapat dikatakan hasil belajar IPA dinilai telah tuntas.

\section{PENUTUP}

\section{Simpulan}

Berdasarkan hasil kegiatan pembelajaran yang telah dilakukan selama dua siklus, dan berdasarkan seluruh pembahasan serta analisis yang telah dilakukan dapat disimpulkan bahwa, hasil belajar IPA pada materi pokok Ketergantungan Manusia dan Hewan Pada Tumbuhan 
Volume 3, No. 2 Januari 2020

Kelas V SLB-A TPA Jember dapat meningkat melalui penerapan Metode Karya Wisata. Hal ini dapat dilihat bahwa hasil akhir siklus pembelajaran ke II ini semakin meningkat dibanding siklus I, dari rata-rata $60 \%$ menjadi $81,67 \%$. Dengan demikian, dapat dikatakan hasil belajar IPA pada siklus II dinilai telah tuntas.

\section{Saran}

1. Untuk melaksanakan metode Karya Wisata memerlukan persiapan yang cukup matang, sehingga guru harus mampu menentukan atau memilih topik yang benar-benar bisa diterapkan dengan metode Karya Wisata dalam pembelajaran sehingga diperoleh hasil yang optimal.

2. Dalam rangka meningkatkan prestasi belajar siswa, guru hendaknya lebih sering melatih siswa dengan berbagai metode pembelajaran, walau dalam taraf yang sederhana, dimana siswa nantinya dapat menemukan pengetahuan baru, memperoleh konsep dan keterampilan, sehingga siswa berhasil atau mampu memecahkan masalahmasalah yang dihadapinya.

3. Perlu adanya penelitian yang lebih lanjut, karena hasil penelitian ini hanya dilakuakan di SLB-A TPA Jember

\section{DAFTAR PUSTAKA}

Arikunto, Suharsimi. (2001). Dasardasar Evaluasi Pendidikan. Jakarta: Bumi Aksara.

Arikunto, Suharsimi. (2002). Prosedur Penelitian Suatu Pendekatan Praktek. Jakarta:Rineksa Cipta.

http://doi.org/10.31537/speed.v3i2.280
Combs. Arthur. W. (1984). The Profesional Education of Teachers. Allin and Bacon, Inc. Boston.

Dahar, R.W. (1989). Teori-teori Belajar. Jakarta: Erlangga.

Departemen Pendidiakan dan Kebudayaan, (1994). Petunjuk Pelaksanaan Proses Pembelajaran. Jakarta. Balai Pustaka.

Djamarah, Syaiful Bahri. (2002). Metode pembelajaran. Jakarta: Rineksa Cipta.

Eggen dan Kauchak, "Konsep Dasar Pembelajaran", Online: http://persimpangan.woordpres.c om/ (6 Agustus 2013)

Erriniati, (1997). Penerapan Strategi Motivasi Belajar Siswa dalam Proses Belajar Menajar Fisika Pokok Bahasan Listrik Statis Kelas VI B Cawu III Tahun Pelajaran 1996/1997 di SLTPN 23 Surabaya. Skripsi yang tidak dipublikasikan. Universitas Negeri Surabaya.

Hamalik, Oemar. (2000). Psikologi Belajar dan Mengajar. Bandung: Sinar Baru Algesindo.

Hasibuan, J.J. dan Moerdjiono. (1998). Proses Pembelajaran. Bandung: Remaja Rosdakarya.

Kemmis, S. dan Mc. Taggart, R. (1988). The Action Research Planner. Victoria Dearcin University Press.

Liang Gie. (1993). Cara Belajar Yang Efisien. Yogyakarta: Universitas Gajah Mada

Moedjadi. (2000). Pengelolaan Laboratorium Sekolah. Bandung: Tarsito 
Volume 3, No. 2 Januari 2020

Moestaqim. (1991). Pengelolan Laboratorium Sekolah. Bandung: Tarsito

Nasution. S. (2002). Didaktik AzasAzas Mengajar. Bandung: Jemmars

Ningsih, Asri Budi. (2005). Belajar Dan Pembelajaran. Jakarta: Renika Cipta

Nur, Moh. (2001). Pemotivasian Siswa untuk Belajar. Surabaya. University Press. Universitas Negeri Surabaya.

Poerwodarminto. (1991). Kamus Umum Bahasa Indonesia. Jakarta:Bina Ilmu.

Purwanto, Ngalim M. (1996). Psikologi Pendidikan. Bandung: Fakultas Ekonomi

Rustiyah, N.K. (1991). Metode pembelajaran. Jakarta: Bina Aksara.

Silberman. (2009). Aktif Learning 101 Metode pembelajaran Aktif. Yogyakarta: Pustaka Insan Madani.

Soetomo. (1993). Dasar-dasar Interaksi Pembelajaran. Surabaya Usaha Nasional

Soetopo, Hendyat. (2000). Pengantar Dasar-Dasar Administrasi Pendidikan. Malang: Fakultas Ilmu Pendidikan

Sukarno, Hadiat Kertiasa, (2001). Dasar-Dasar Pendidikan Science. Jakarta: Bahtera

Sukidin, et.al. (2002). Manajemen Penelitian Tindakan Kelas. Surabaya: Insan Cendekia.

Sulaiman, Darwis

A. (1997). Pengantar Kepada Teori Dan Praktek Pengajaran, Semarang: Semarang Press
Suryosubroto. (1997). Proses Pembelajaran di Sekolah. Jakarta: Rineksa Cipta

Syah, Muhibbin. (1995). Psikologi Pendidikan, Suatu Pendekatan Baru. Bandung: Remaja Rosdakarya.

Uno, Hamzah $\quad$ B. (2009). Model Pembelajaran Menciptakan Pembelajaran Yang Kreatif Dan Efektif. Jakarta: Bumi Aksara

Uzer, Usman, (2000). Menjadi Guru Profesional. Bandung:PT. Remaja Rosdakarya.

Winkel. (2004). Motivasi Dan Prestasi Belajar. Jakarta: Gunung Agung

Zaini, Hisyam, (2008). Metode pembelajaran Aktif. Yogyakarta: Insan Madani 